This allows the reader to compare the spectrum of these women's writings within a common theme.

The volume is to be admired for its meticulous archival research, its limpid and concise style, and its readable and fluent English rendering of complicated Italian syntax and ambiguous lexical constructions. Not only the translation, transcription, and editing criteria but also the notes on metre, rhythm, and rhyme make this collection accessible to a wide range of readers. Cox's inclusion of previously excluded poems accompanied by literary analysis and metrical schemes will help a broader audience understand these poets' lyric production. It will also allow scholars to consult these poems in their original language. This is particularly useful since some are available only in manuscript or in difficultto-find early modern printed editions.

This superb anthology represents a refreshing formalist approach to these writers and a useful engagement with texts unfamiliar to many scholars. It constitutes a major advance in our understanding of secular and religious lyric poetry in the Renaissance. With its valuable introduction and commendably readable translation, this book can be assigned in classes on early modern poetry, at both the undergraduate and graduate level.

LAURA PRELIPCEAN

Concordia University

\title{
Dooley, Brendan.
}

A Mattress Maker's Daughter: The Renaissance Romance of Don Giovanni de' Medici and Livia Vernazza.

Cambridge, MA: Harvard University Press, 2014. Pp. xiv, 454. ISBN 978-0-67472466-2 (hardcover) \$49.95.

In Catholic grand-ducal Florence ruled by Christine de Lorraine and Maria Magdalena of Austria was it possible to have a love story involving different social classes and a Medici scion?

Brendan Dooley offers a compelling example, while showing that the price paid by the two lovers was so high as to make their own belief in the possibility and legitimacy of their love truly astonishing. Don Giovanni de' Medici, an illegitimate son of Cosimo de' Medici and Eleonora degli Albizi, 
was born in 1567; sometime around 1609 he met Livia Vernazza, the nineteenyear-old daughter of a Genoese mattress maker. The story narrated by Dooley is firmly based on the letters exchanged by Giovanni and Livia and now housed in the Miscellanea Medicea, a sub-collection of the larger "Mediceo del Principato" collection of the State Archives in Florence.

Like so many other young women in Italy at that time, Livia was betrothed by her father and brothers to an older man, a mattress maker like her father. She was expected to submit to this marriage along with violence on both her paternal side (in order to "convince" her to accept the decision) and on the marital (in order to accept the "reality" of this decision made for her). Livia experienced directly the contradictions emanating from the "Tametsi" decree issued by the Council of Trent, which considered legal a marriage freely entered into by the two partners. Livia, however, did not accept her family's decision, or the domestic violence it entailed, and so she ran away from Genoa. Giovanni, on the other hand, lived his life as a minor member of the Medici family; though born out of wedlock, he had subsequently been legitimized by the family. He was closer to his half-brother Grand Duke Francesco-sharing with him a love for knowledge and the study of various sciences, alchemy in particular-than to his half-brother Cardinal Ferdinando (later to become Grand Duke Ferdinando), whose religious side did not fit Giovanni's interests. "As a legitimized-not legitimate-child, for all intents, an orphan, outside the line of succession to the grand ducal throne, the career options [open to Giovanni] were limited, and some were out of question" (28). He thus pursued a military career, serving as a commander in the wars in Flanders and in the Venetian wars against the emperor. But he was also very interested in architecture, poetry, forbidden books, fortifications, alchemy, and theatre. An accomplished Renaissance man, his only fault, in the eyes of his contemporaries, was that he fell in love with a woman from a much lower social status.

Giovanni tried to protect Livia as much as he could, remembering that his own mother, Eleonora degli Albizi, had been enclosed for years in a convent, accused of having betrayed her family, and then obliged to marry a courtier in order to save appearances. In spite of his efforts, Giovanni-and Livia in particular-had to face the stubborn hostility, stern morality, and open greed of both living grand duchesses: Christine of Lorraine, wife of Grand Duke Ferdinando I, and Maria Magdalena von Habsburg, wife of Grand Duke Cosimo II. After Giovanni's death abroad (in Murano in 1621), a long and 
harsh battle ensued that sought to deprive Giovanni Francesco (the legitimate son of Giovanni and Livia) of his legal rights and to "forget" the existence of Livia, who was deemed to be "arrogant" because she sought to defend her property, her rights, and her inheritance by mounting a long resistance, both in life and in the courts. After being carried away from Venice, by deceit, she was kept prisoner in Florence, in the Fortezza di Belvedere, for almost sixteen years, forgotten by nearly everyone. She was rescued by chance and, through the authorization of Grand Duke Ferdinando II, allowed to spend her final days in the villa Le Macine, in Montughi, where she died in 1655. The last outrage against her was perpetrated by her only surviving child, Giovanni Francesco Maria, who had been raised at court after his father's death; the son considered his mother to be a whore and even attempted to harm her physically.

Giovanni and Livia's story thoroughly engages the reader. Dooley's narrative presents a vivid image of life in Florence and at the Medici court, while providing a compelling analysis of Giovanni's and Livia's feelings and thoughts. The reader almost can "see" and "feel" what Livia and Giovanni were going through. Though primarily the narrative of a love story, the volume also provides its readers with a fine analysis of the legal, social, intellectual, and religious realities of the time, all explained with great clarity. The most important aspects of the book, however, are the careful reading of the primary sources and the balanced interpretation of these sources. As such, this work is an excellent example of how microhistory should be approached and written.

ELENA BRIZIO

The Medici Archive Project, Florence

\section{Feigenbaum, Gail with Francesco Freddolini.}

\section{Display of Art in the Roman Palace 1550-1750.}

Los Angeles: The Getty Research Institute, 2014. Pp. xiv, $368+50$ colour and 118 b/w ill. ISBN 978-1-60606-298-2 (hardcover) \$75.

This beautifully illustrated book about display in Roman baroque palaces (50 colour and 118 black-and-white images) was produced by a team of scholars who worked at the Getty Research Institute on the annual scholar theme devoted to "Display of Art." This year of research obviously yielded rich results for 